\title{
Clara cell protein as a biomarker for ozone-induced lung injury in humans
}

\author{
A. Blomberg*, I. Mudway\#, M. Svensson ${ }^{\mp}$, A. Hagenbjörk-Gustafsson ${ }^{+}$, L. Thomasson ${ }^{+}$, R. Helleday*, \\ X. Dumont ${ }^{\S}$, B. Forsberg", G. Nordberg", A. Bernard ${ }^{\S}$
}

Clara cell protein as a biomarker for ozone-induced lung injury in humans. A. Blomberg, I. Mudway, M. Svensson, A. Hagenbjörk-Gustafsson, L. Thomasson, R. Helleday, X. Dumont, B. Forsberg, G. Nordberg, A. Bernard. (C) ERS Journals Ltd 2003.

ABSTRACT: Exposure to ozone $\left(\mathrm{O}_{3}\right)$ impairs lung function, induces airway inflammation and alters epithelial permeability. Whilst impaired lung function and neutrophilia have been observed at relatively low concentrations, altered lung epithelial permeability is only seen after high-dose challenges. The appearance of Clara cell protein $(\mathrm{CC} 16)$ in serum has been proposed as a sensitive marker of lung epithelial injury. Here, the use of $\mathrm{CC16}$ as an injury biomarker was evaluated under a controlled exposure to $\mathrm{O}_{3}$ and the relationship between this marker of lung injury and early lung function decrements was investigated.

Subjects $(\mathrm{n}=22)$ were exposed on two separate occasions to 0.2 parts per million $\mathrm{O}_{3}$ and filtered air for $2 \mathrm{~h}$. Blood samples were drawn and lung function assessed at $2 \mathrm{~h}$ preexposure, immediately before and immediately after exposure as well as 2 and $4 \mathrm{~h}$ postexposure.

$\mathrm{O}_{3}$ increased $\mathrm{CC1} 16$ serum concentrations at $2 \mathrm{~h}\left(12.0 \pm 4.5\right.$ versus $\left.8.4 \pm 3.1 \mu \mathrm{g} \cdot \mathrm{L}^{-1}\right)$ and $4 \mathrm{~h}$ postexposure $\left(11.7 \pm 5.0\right.$ versus $\left.7.9 \pm 2.6 \mu \mathrm{g} \cdot \mathrm{L}^{-1}\right)$ compared with air concentrations. Archived samples from $\mathrm{O}_{3}$ studies utilising the same design indicated that this increase was sustained for up to $6 \mathrm{~h}$ postexposure $\left(9.1 \pm 2.6 \mathrm{versus} 7.1 \pm 1.7 \mu \mathrm{g} \cdot \mathrm{L}^{-1}\right)$ with concentrations returning to baseline by $18 \mathrm{~h}\left(7.7 \pm 2.9\right.$ versus $\left.6.6 \pm 1.7 \mu \mathrm{g} \cdot \mathrm{L}^{-\mathrm{P}}\right)$. In these studies, the increased plasma CC16 concentration was noted in the absence of increases in traditional markers of epithelial permeability. No association was observed between increased CC16 concentrations and lung function changes.

To conclude, Clara cell protein represents a sensitive and noninvasive biomarker for ozone-induced lung epithelial damage that may have important uses in assessing the health effects of air pollutants in future epidemiological and field studies.

Eur Respir J 2003; 22: 883-888.
*Dept of Respiratory Medicine and Allergy, University Hospital, "Environmental and Occupational Medicine, Dept of Public Health and Clinical Medicine, Umeå University, and ${ }^{+}$National Institute for Working Life, Umeå, Sweden. ${ }^{\#}$ School of Health and Life Sciences, King's College London, London, UK. 'Industrial Toxicology Unit, Faculty of Medicine, Catholic University of Louvain, Brussels, Belgium.

Correspondence: A. Blomberg, Dept of Respiratory Medicine and Allergy, University Hospital, SE-901 85 Umeå, Sweden. Fax: 4690141369

E-mail: anders.blomberg@lung.umu.se

Keywords: Air pollution, biomarkers, Clara cell protein, lung permeability, ozone

Received: May 12003

Accepted after revision: July 162003

This study was supported by the European Commission HELIOS project (QLK4CT1999-01308), the Swedish Heart-Lung Foundation, Umeå University, the Swedish Environmental Protection Agency and the Swedish Research Council for Environment, Agricultural Sciences and Spatial Planning (FORMAS), Sweden.
Ozone $\left(\mathrm{O}_{3}\right)$ is an important component of photochemical air pollution to which large numbers of the population are exposed during the summer months. Human exposures to $\mathrm{O}_{3}$ have been shown to elicit a spectrum of acute responses including lung function decrements [1], increased airway resistance [2], altered airway permeability [3], perturbation of antioxidant defences [4, 5] and airway neutrophilia [3, 6, 7]. While the measurement of altered lung function is relatively easy and amenable for use in population-based studies, assessment of airway inflammation and epithelial lung injury have proven more demanding of time and resources, especially where bronchoscopy-based lavage has been performed. Importantly, several studies have failed to find an association between $\mathrm{O}_{3}$-induced lung function decrements and airway inflammation [4, 8], suggesting the absence of a casual relationship between these two symptomatic responses. The use of induced sputum $[9,10]$, nasal lavage [11, 12], or the measurement of exhaled gases [10] and breath condensate [13] has been championed by many as providing less invasive methods for assessing pulmonary responses to acute air pollution challenges. In all cases, these methods have successfully demonstrated increased markers of inflammation following acute air pollutant challenges but how these results relate to distal pulmonary events remains oblique $[12,14$, 15]. In contrast, these methods have failed to demonstrate increased permeability in these studies using traditional markers of lung injury, i.e. albumin, total protein, etc.

Tests based on the appearance of lung-specific proteins in serum following an airway insult have been proposed as a noninvasive and highly sensitive alternative to traditional markers of lung epithelial injury. This approach is based on the concept that these lung-specific proteins move passively across the epithelial barrier into the serum where they may serve as peripheral indicators of epithelial damage [16]. One of the most studied candidate proteins for this analysis is Clara cell protein (CC16), a $16 \mathrm{kD}$ anti-inflammatory protein secreted by the nonciliated bronchiolar Clara cells [17]. Serum $\mathrm{CC} 16$ has been used to detect increased epithelial permeability in a variety of clinical and experimental situations such as in sarcoidosis [18] and after exposure to tobacco smoke [19] and nitrogen trichloride [20]. It has also been suggested as a marker of $\mathrm{O}_{3}$-induced epithelial damage. Cyclists exposed to ambient air for $2 \mathrm{~h}$ demonstrated increased serum $\mathrm{CC} 16$ concentrations when $\mathrm{O}_{3}$ ranged 33-103 parts per billion, and a correlation was found between $\mathrm{O}_{3}$ concentration and the concentration of $\mathrm{CC} 16$ in serum [21]. This observation 
suggested that the pulmonary epithelium was more sensitive to $\mathrm{O}_{3}$ than had been suggested using traditional permeability markers in airway lavage. These data were based on a field study with subjects exposed to a range of air pollutants making it difficult to attribute these effects directly to $\mathrm{O}_{3}$. The aim of this study was therefore to address the utility of serum $\mathrm{CC} 16$ as a biomarker for $\mathrm{O}_{3}$-specific epithelial injury in subjects exposed under controlled chamber conditions, and to relate changes in this marker to early $\mathrm{O}_{3}$-induced lung function decrements.

\section{Subjects and methods}

\section{Subjects}

Healthy subjects $(n=22,12$ female, 10 male; mean age 24 yrs, range $21-43$ yrs) were recruited. All were nonsmokers with normal lung function and no history of allergy or preexisting lung disease. Subjects were free of airway infection for $\geqslant 4$ weeks prior to the first exposure and throughout the remainder of the study. Volunteers provided written informed consent and the study was approved by the Umeå University Ethics Committee.

\section{Study design and exposures}

The study was conducted in a single-blinded, crossover control fashion, with volunteers exposed in random order to separate filtered air and 0.2 parts per million (ppm) $\mathrm{O}_{3}$ challenges according to a standard protocol [4]. Successive exposures were separated by $\geqslant 3$ weeks. Exposures lasted for $2 \mathrm{~h}$ with subjects performing alternate 15-min cycles of moderate exercise (minute ventilation $20 \mathrm{~L} \cdot \mathrm{min}^{-1} \cdot \mathrm{m}^{-2}$ ) and rest. Lung function was assessed and peripheral blood samples were obtained at five time points throughout the protocol: 1) $2 \mathrm{~h}$ before the exposure $(-2 \mathrm{~h})$, immediately before, immediately postexposure $(0 \mathrm{~h})$ and at $2(2 \mathrm{~h})$ and 4 $(4 \mathrm{~h}) \mathrm{h}$ after the end of the exposure. Two pre-exposure time points were used in an attempt to establish a stable baseline concentration of $\mathrm{CC} 16$.

\section{Lung function assessments}

Lung function tests (vital capacity (VC) and forced expiratory volume in one second (FEV1)) were carried out using a conventional Vitalograph spirometer (Vitalograph Med. Instruments $\mathrm{GmbH}$, Hamburg, Germany). At least three satisfactory measurements were performed in accordance with the recommendation of the American Thoracic Society [22].

\section{Blood sampling}

Peripheral blood samples $(10 \mathrm{~mL})$ were obtained by venipuncture with collections into dry tubes (BD vacutainer type ST; BD vacutainer systems, Preanylitical Solutions Plymouth, UK). Each sample was allowed to clot for a minimum of $1 \mathrm{~h}$ at room temperature. Samples were then centrifuged at $3,000 \times g$ for $12 \mathrm{~min}$ and serum decanted and stored at $-80^{\circ} \mathrm{C}$ until protein analysis. $\mathrm{CC} 16$ was determined by latex immunoassay using a rabbit anti-CC16 antibody (Dakopatts, Glostrup, Denmark) and CC16 purified at the Industrial Toxicology Unit, Faculty of Medicine, Catholic University of Louvain, Brussels, Belgium, as standards [23].
All samples were run in duplicate at two different dilutions. This assay has been validated previously by comparison with a monoclonal antibody-based enzyme-linked innumosorbent assay [24]. The between- and within-run coefficients of variation range $5-10 \%$. Previous studies have shown that serum concentrations of $\mathrm{CC} 16$ in normal healthy subjects, on average, range $10-15 \mu \mathrm{g} \cdot \mathrm{L}^{-1}[17]$.

\section{Details of archived study material}

Later time points following $\mathrm{O}_{3}$ challenge were assessed using archived plasma samples from two recent studies [5, 7, 25]. In both investigations, exposure protocols were identical to those outlined in the present study. The first study comprised 15 healthy subjects (six males, nine females; mean age 24 yrs, range 19-31 yrs) exposed to air and $\mathrm{O}_{3}$ as outlined previously, with blood drawn pre- and $6 \mathrm{~h}$ postexposure. In addition, bronchoscopy-based airway lavages were performed at $6 \mathrm{~h}$ postexposure, immediately following the final blood sampling. Details of the lavage technique have been described previously [5]. These samples were analysed for total protein and albumin, using assays from Boehringer, Mannheim, Germany in an autoanalyser at the Dept of Clinical Chemistry, University Hospital, Umeå, Sweden. The second study involved another 15 healthy subjects (five females, 10 males; mean age 23 yrs, range 21-27 yrs). Here, blood samples were collected pre-exposure and $18 \mathrm{~h}$ postexposure. Bronchoscopy was carried out immediately after the final plasma samples were drawn, in an identical fashion to the 6-h study. Permeability markers were also assessed as described above. Whole blood samples obtained at the time points above were immediately centrifuged at $4{ }^{\circ} \mathrm{C}$ at $400 \times g$ and stored at $-80^{\circ} \mathrm{C}$. These archived plasma samples were used for CC16 analyses, using the method outlined above.

\section{Statistical analyses}

All data are summarised as mean \pm SD. A repeated measures analysis of variance (General Linear Model) with two withinsubject factors (time and exposure) was used. The immediate pre-exposure time point was used as reference. The $-2 \mathrm{~h}$ data were excluded from the statistical analyses, since rather than demonstrating a stable baseline in the period prior to exposure, values fell significantly between $-2 \mathrm{~h}$ and immediate pre-exposures. Comparison across intervals was conducted using a paired t-test. Correlation analyses were carried out both between baseline data and $\Delta$ values (value after $\mathrm{O}_{3}$ minus value after air) using Pearson's correlation coefficient. A p-value of $<0.05$ was considered significant. However, in order to avoid type-I errors due to three comparisons, the level of significance was adjusted by dividing the set significance level by three (Bonferroni correction). Thus, a p-value of $<0.017$ was considered significant.

\section{Results}

Exposure to $0.2 \mathrm{ppm}$ of $\mathrm{O}_{3}$ significantly increased the serum CC16 concentrations at the $2 \mathrm{~h}$ and $4 \mathrm{~h}$ postexposure time points relative to parallel air exposure values $(12.0 \pm 4.5$ versus $8.4 \pm 3.1 \mu \mathrm{g} \cdot \mathrm{L}^{-1}, \mathrm{p}<0.001$ and $11.7 \pm 5.0$ versus $7.9 \pm$ $2.6 \mu \mathrm{g} \cdot \mathrm{L}^{-1}, \mathrm{p}<0.001$, respectively). $\mathrm{O}_{3}$ serum $\mathrm{CC} 16$ concentrations at $2 \mathrm{~h}$ postexposure were significantly increased compared with the immediate pre-exposure value $(\mathrm{p}<0.01)$. This was not the case when comparing the $4 \mathrm{~h}$ postexposure and immediate pre-exposure values $(\mathrm{p}=0.036)$, though a clear trend still existed. In contrast, after air challenge, serum CC16 

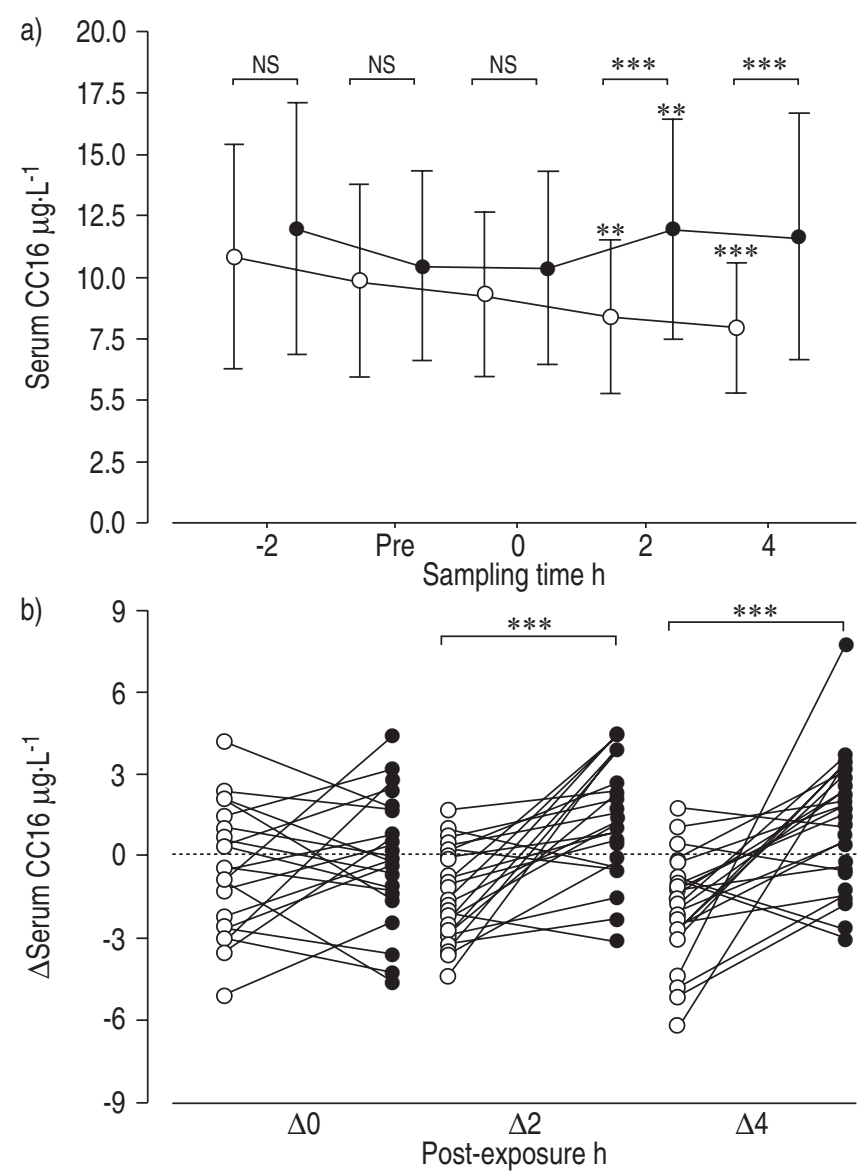

Fig. 1.-Serum Clara cell protein (CC16) concentrations (mean \pm SD) after exposure to air $(\bigcirc)$ and 0.2 parts per million ozone $\left(\mathrm{O}_{3} ; \mathbf{\bullet}\right)$. a) Illustrates serum CC16 concentrations $\left(\mu \mathrm{g} \cdot \mathrm{L}^{-1}\right)$ at each of the sampling points throughout the air and $\mathrm{O}_{3}$ exposures. The 2-h exposure duration encompassed the pre and $0 \mathrm{~h}$ time periods. Statistical comparisons were made using a repeated measures analysis of variance (general linear model) with two within-subject factors for time and exposure. p-Values above a bar illustrate a significant increase in serum $\mathrm{CC} 16$ after $\mathrm{O}_{3}$ compared with the parallel air exposure value. A p-value on the individual points represents a significant change between the investigated time point and the corresponding pre-exposure value. b) Illustrates the individual changes in serum CC16 concentration $\left(\mu \mathrm{g} \cdot \mathrm{L}^{-1}\right)$ observed after air and $\mathrm{O}_{3}$ challenge at the 0,2 and $4 \mathrm{~h}$ postexposure time points relative to the corresponding pre-exposure concentration. Statistical comparison of these changes across treatments was made using a paired t-test and the level of significance observed is illustrated. NS: nonsignificant; **: $\mathrm{p}<0.01 ; * * *: \mathrm{p}<0.001$.

concentrations were significantly decreased $2 \mathrm{~h}$ and $4 \mathrm{~h}$ postexposure compared with the pre-air exposure concentration ( $\mathrm{p}<0.01$ and $\mathrm{p}<0.001$, respectively; fig. 1).

$\mathrm{O}_{3}$ induced a significant decrease in FEV1 immediately postexposure $(0 \mathrm{~h}), \mathrm{p}=0.002$ (fig. 2 ). A corresponding fall was also detected in VC $(\mathrm{p}=0.001)$. Lung function values were not significantly decreased at the $2 \mathrm{~h}$ and $4 \mathrm{~h}$ postexposure time points. No significant correlations were observed between baseline serum CC16 concentration and baseline lung function values. Neither was any relationship noted between the CC16 and lung function (ozone minus air) responses at any time point postexposure.

When analysing plasma from archived material, it was found that the $\mathrm{O}_{3}$ exposure resulted in an increase in $\mathrm{CC} 16$ concentrations that persisted until $6 \mathrm{~h}$ postexposure $(9.1 \pm 2.6$ versus $\left.7.1 \pm 1.7 \mu \mathrm{g} \cdot \mathrm{L}^{-1} ; \mathrm{p}<0.01\right)$ but returned to control values at the $18 \mathrm{~h}$ postexposure time point (fig. 3). It should be noted
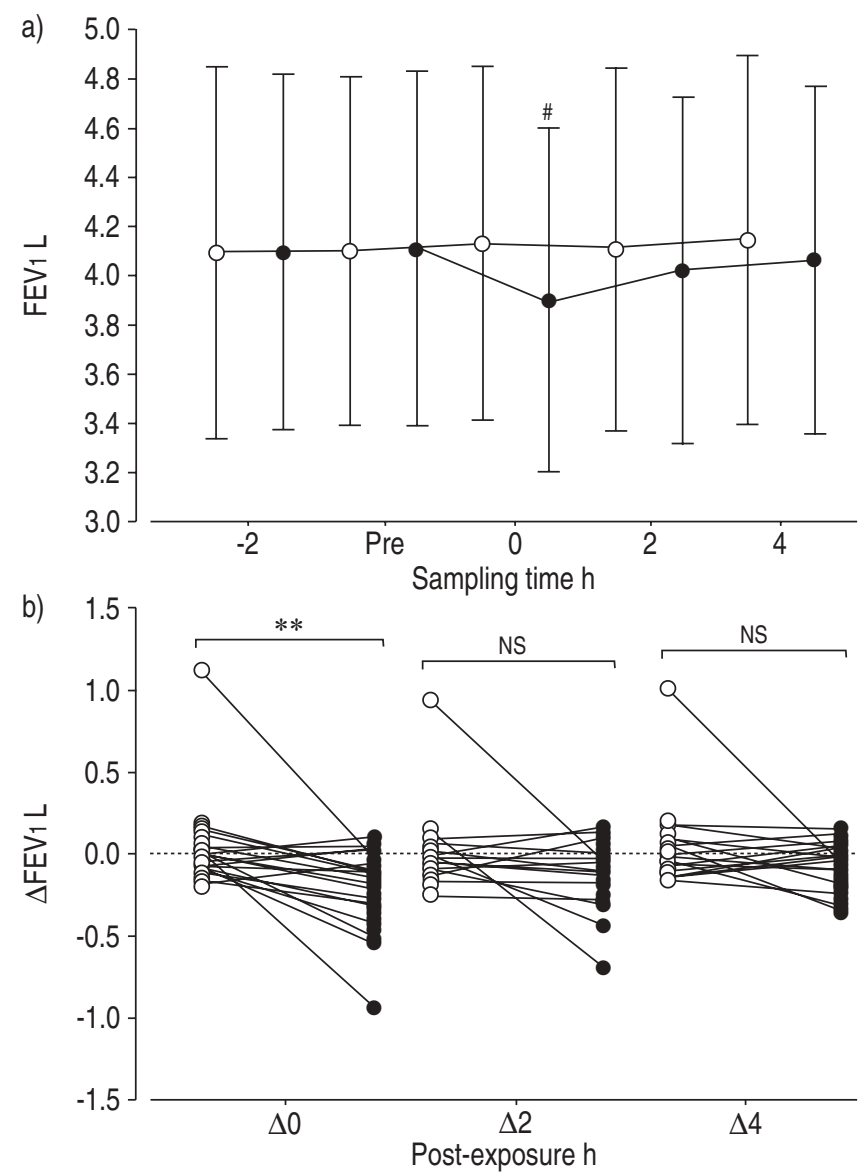

Fig. 2. - Forced expiratory volume in one second (FEV1) measured at prescribed intervals prior to, and at various points after, air $(\bigcirc)$ and 0.2 parts per million of ozone $\left(\mathrm{O}_{3} ;-\right.$ ) exposure. a) Illustrates overall FEV1 responses at each of the sampling points throughout the air and $\mathrm{O}_{3}$ exposures. The 2-h exposure duration encompassed the pre and $0 \mathrm{~h}$ time periods. Statistical comparisons were made using a repeated measures analysis of variance (general linear model) with two within-subject factors for time and exposure. p-Values above a bar illustrate a significant decrease in FEV1 after $\mathrm{O}_{3}$ compared with the parallel air exposure value. A p-value on the individual points represents a significant change between the investigated time point and the corresponding pre-exposure value. b) Illustrates the individual changes in FEV 1 observed after air and $\mathrm{O}_{3}$ challenge at the 0,2 and $4 \mathrm{~h}$ postexposure time points relative to the corresponding preexposure. Statistical comparison of these changes across treatments was made using a paired t-test and the level of significance observed is illustrated. NS: nonsignificant; ${ }^{* *}: \mathrm{p}<0.01 ;{ }^{*}: \mathrm{p}=0.002$.

that a significant difference between baseline concentrations of $\mathrm{CC} 16$ in serum versus plasma was observed, with serum concentrations significantly higher $(\mathrm{p}<0.001)$. However, as the difference in $\mathrm{CC} 16$ concentrations between the $\mathrm{O}_{3}$ and air exposures is considered, and not the absolute values, no problems are expected comparing the $\mathrm{O}_{3}$-induced differences in CC16 plasma concentrations seen in the archived material with the changes in $\mathrm{CC} 16$ serum concentrations in the present study. Notably, a high degree of intrasubject stability in serum and plasma CC16 concentrations was observed when sampled over a period of $\geqslant 3$ weeks $(r=0.83, p<0.0001$; fig. 4).

No significant increase was seen in permeability marker concentrations measured in lavage fluid obtained $6 \mathrm{~h}$ postexposure despite the evidence of increased plasma CC16 concentration at this time. In the proximal airways, sampled with a bronchial wash, post- $\mathrm{O}_{3}$ and postair concentrations, respectively, were: albumin $\left(32.2 \pm 19.4\right.$ versus $\left.32.6 \pm 14.0 \mu \mathrm{g} \cdot \mathrm{mL}^{-1}\right)$ and total protein $\left(53.9 \pm 24.7\right.$ versus $\left.44.8 \pm 23.5 \mu \mathrm{g} \cdot \mathrm{mL}^{-1}\right)$. 


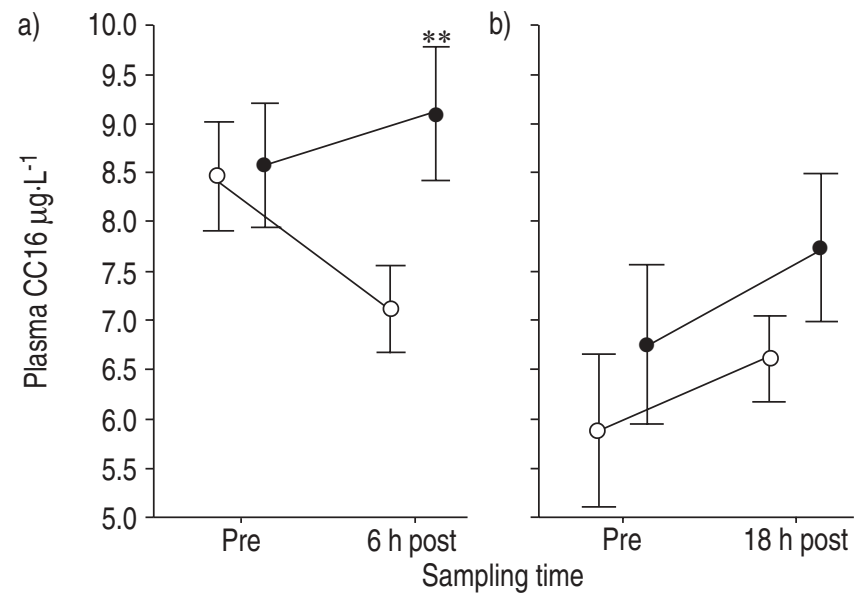

Fig. 3. - Plasma Clara cell protein (CC16) concentrations a) 6 and b) $18 \mathrm{~h}$ postexposure after controlled exposures to air $(O)$ and 0.2 parts per million of ozone $(\bullet)$. Corresponding pre-exposure concentrations are also illustrated. Data are illustrated as group mean \pm SD with statistical analysis performed as outlined in figure $1 .{ }^{* *}: \mathrm{p}<0.01$.

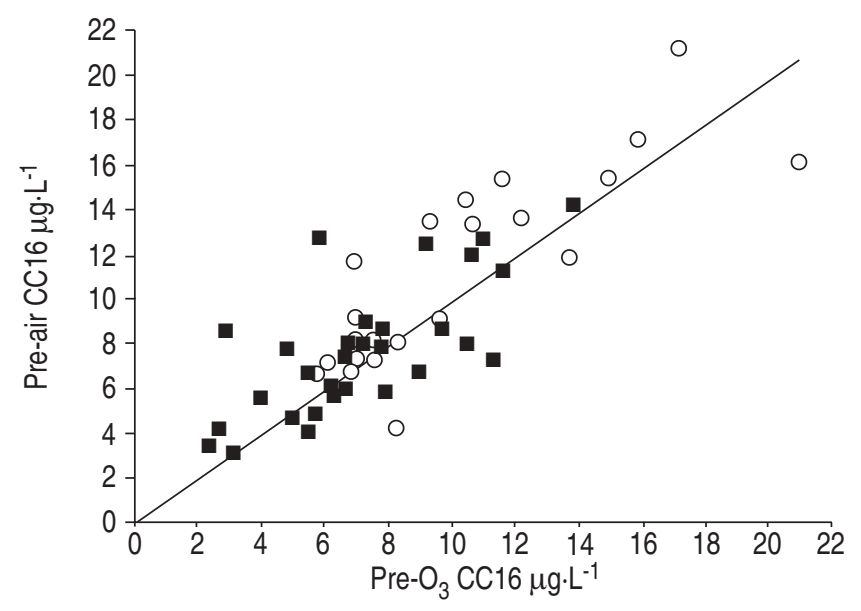

Fig. 4. - The correlation between individual serum $(O, n=22)$ and plasma $(\boldsymbol{\square}, \mathrm{n}=30)$ Clara cell protein $(\mathrm{CC} 16)$ concentrations seen preozone $\left(\mathrm{O}_{3}\right)$ and pre-air challenges but separated by a period of $\geqslant 3$ weeks. The strength of the temporal association between these individual values was tested using Pearson's correlation and the result of this analysis is illustrated. Data are shown relative to the line of identity to illustrate the degree of intrasubject repeatability. $R=0.83, p<0.0001$.

These markers were also examined in distal lung bronchoalveolar lavage fluid post- $\mathrm{O}_{3}$ and air, respectively: albumin $\left(44.9 \pm 21.0\right.$ versus $\left.37.2 \pm 17.2 \mu \mathrm{g} \cdot \mathrm{mL}^{-1}\right)$ and total protein $(54.4 \pm$ 29.8 versus $45.1 \pm 23.8 \mu \mathrm{g} \cdot \mathrm{mL}^{-1}$ ). These parameters (post- $\mathrm{O}_{3}$ and postair, respectively) were also measured in these lavage fractions at $18 \mathrm{~h}$ postexposure where they remained unaltered: in bronchial wash, albumin $(34.6 \pm 24.0$ versus $43.9 \pm 40.6 \mu \mathrm{g}$. $\left.\mathrm{mL}^{-1}\right)$ and total protein $\left(71.0 \pm 41.6\right.$ versus $\left.92.7 \pm 79.2 \mu \mathrm{g} \cdot \mathrm{mL}^{-1}\right)$, and in bronchoalveolar lavage, albumin $(54.6 \pm 25.4$ versus $\left.51.1 \pm 23.9 \mu \mathrm{g} \cdot \mathrm{mL}^{-1}\right)$ and total protein $(84.4 \pm 45.0$ versus $\left.83.3 \pm 48.4 \mu \mathrm{g} \cdot \mathrm{mL}^{-1}\right)$.

\section{Discussion}

This is the first experimental study to address the effect of $\mathrm{O}_{3}$ on serum $\mathrm{CC} 16$ concentrations in healthy subjects exposed under controlled chamber conditions. Following $\mathrm{O}_{3}$, an early increase in CC16 in the systemic circulation was observed, peaking around $2-4 \mathrm{~h}$ postexposure before returning to baseline levels $18 \mathrm{~h}$ postexposure. As CC16 is synthesised and secreted almost exclusively by the lung Clara cells, the enhanced serum concentration can only be explained by a leakage of the protein across the lung epithelial barrier [16, 26]. This finding is in agreement with the enhanced serum levels of $\mathrm{CC} 16$ obtained from cyclists exposed to $\mathrm{O}_{3}$ in the environment, as the main oxidant in summer photochemical smog $[21,27]$. Notably, no association was observed between the magnitude of the $\mathrm{O}_{3}$-induced lung function decrements and $\mathrm{CC} 16$ responses, suggesting that impaired lung function was not related to epithelial injury.

A number of caveats are necessary when comparing the results of the current chamber exposure with the earlier field study of training cyclists. Here, volunteers were exposed to a higher $\mathrm{O}_{3}$ concentration 0.2 ppm versus $0.033-0.103$ ppm [21, 27]. Despite this quantitative difference, it is likely that the overall dose may have been much closer, due to the exercise level of the training cyclists. An additional confounder is the degree of pre-exposure between the two studies. As the field study took place in summer, the cyclists were exposed to reasonably high $\mathrm{O}_{3}$ concentrations for several days before the day of the study. In contrast, the exposures in the chamber study were performed in the winter when background $\mathrm{O}_{3}$ levels were low $(<0.02 \mathrm{ppm})$. In the field study, the pre-ride $\mathrm{CC} 16$ levels increased with increasing background $\mathrm{O}_{3}$ concentrations, indicating that the cyclists already had an enhanced permeability of the lung epithelium at baseline. During exercise under high pollutant levels, increased serum concentrations of CC16 were detected immediately after the 2 -h exposure [21]. This early response differed from the current study in which elevations in CC16 were observed no earlier than $2 \mathrm{~h}$ postchallenge and may reflect a degree of preexisting $\mathrm{O}_{3}$-induced epithelial damage in the cyclists. However, it cannot be excluded that other important air pollutants in the photochemical smog, such as nitrogen dioxide or particulate matter pollution, may have affected CC16 leakage in the early postride period.

This study confirms that short-term $\mathrm{O}_{3}$ exposure results in increased epithelial permeability. Given previous observations from human challenge studies, this would appear to correspond to the period of neutrophil recruitment into the proximal airways $[4,6,7]$. Support for this notion has been demonstrated in mice where $\mathrm{O}_{3}$-induced increases in serum CC16 are accompanied by neutrophil influx into the airways. In this study the authors also demonstrated an increased concentration in bronchoalveolar lavage fluid albumin [27]. In the present study, as in the field study of cyclists, no measurements of airway inflammation were performed. However, in previous investigations using exactly the same study design as in the present investigation, with exposure of healthy subjects to $0.2 \mathrm{ppm}$ of $\mathrm{O}_{3}$ for $2 \mathrm{~h}$, airway inflammation in endobronchial mucosal biopsies at 1.5, 6 and $18 \mathrm{~h}$ postexposure were evaluated. As early as $1.5 \mathrm{~h}$ postexposure, signs of an evolving airway inflammation were observed as increased expression of the endothelial adhesion molecules Pselectin and intercellular adhesion molecule-1, both of major importance in the recruitment of neutrophils into the airway mucosa [4]. At $6 \mathrm{~h}$ postexposure, a pronounced neutrophilic airway inflammation was present, which was resolved by $18 \mathrm{~h}$ postexposure [7, 25]. At neither time point was an increase in airway permeability (measured using classical permeability markers) observed.

As CC16 had been proposed as a sensitive marker of altered permeability, as a secondary hypothesis in this paper, the authors investigated whether early changes in epithelial injury could be associated with acute lung function decrements. Previous studies have failed to find a clear association 
between lung function decrements and airway inflammation $[4,8]$. It has been suggested that lung function decrements are related to stimulation of airway $\mathrm{C}$-fibres [28]. In a previous exposure study, $\mathrm{O}_{3}$ was shown to stimulate the release of substance $\mathrm{P}$ from sensory nerves associated with epithelial injury [29]. In this study, a significant reduction in FEV1 was observed immediately postexposure. At this time, serum CC16 concentrations were not increased after $\mathrm{O}_{3}$. Neither could the magnitude of the FEV1 decrement be related to pre-exposure $\mathrm{CC} 16$ concentrations, nor to the magnitude of the increase seen after $\mathrm{O}_{3}$ at $2 \mathrm{~h}$ postexposure. These findings suggest that these two responses are not simplistically associated.

The data support the contention that serum $\mathrm{CC} 16$ is a more sensitive marker of altered lung epithelial permeability than many of the traditional lavage markers such as albumin and total protein. The explanation for the greater sensitivity of serum CC16 to increased epithelial permeability most probably lies in the small size of the $\mathrm{CC} 16$ protein and the huge transepithelial concentration gradient of CC16 compared with albumin [17]. In light of this, and allied to the relative ease of obtaining peripheral blood samples, it appears that serum CC16 may provide a good biomarker to assess air pollution-induced lung epithelial injury in field studies. While this is highly appealing, several notes of caution are necessary. The consistent fall in CC16 concentrations seen in the control arm of this experiment may imply some form of diurnal variation. This may reflect differential rates of $\mathrm{CC} 16$ secretion from Clara cells, or cyclical changes in the tightness of epithelial/endothelial tight junctions. However, it does necessitate that serum collected for field study use would have to be controlled for sampling time. Additionally, considerable interindividual variation in baseline serum CC16 concentrations was noted in the current study. Despite this, individual values were remarkably consistent across time (fig. 4) suggesting that they were authentic subject characteristics, rather then reflective of measurement error. This baseline variation illustrates that care is required in designing of experiments as baseline variation is often greater than the $\mathrm{O}_{3}$-induced effect on epithelial permeability. It is clear therefore that data must be paired, or if environmental studies are to be performed, responses followed longitudinally. Further, the decrease in CC16 concentrations seen during the air exposure did not appear to be an exercise-induced effect as previous data have shown that short periods of intense exercise actually result in increased plasma CC16 concentrations [20, 30].

To conclude, serum CC16 may be a useful, noninvasive biomarker for air pollution-induced lung epithelial injury with cautionary statements related to potential diurnal variation in serum concentrations, the impact of background exposures on $\mathrm{CC} 16$ responses and the large intersubject variation in baseline concentrations. It is thus suggested that serum $\mathrm{CC} 16$ is a more sensitive marker of altered lung epithelial permeability than traditional markers such as total protein and albumin.

However, as this is the first experimental exposure study addressing the use of Clara cell protein as a biomarker for ozone exposure, further experimental studies are needed to confirm both the relationship between ozone concentrations and serum Clara cell protein concentrations, and whether there is an association between serum Clara cell protein concentrations and traditional markers of permeability after ozone exposure in humans. Studies in more sensitive subpopulations such as individuals with asthma and chronic obstructive pulmonary disease are pending.

Acknowledgements. The authors express their gratitude to $\mathrm{A}$. Johansson and $\mathrm{H}$. Tjällgren for technical assistance and to B. Segerstedt, $\mathrm{H}$. Stenlund and L. Nilsson for statistical advice.

\section{References}

1. Hazbun ME, Hamilton R, Holian A, Eschenbacher WL. Ozone-induced increases in substance $\mathrm{P}$ and 8-epiprostaglandin F2 alpha in the airways of human subjects. Am J Respir Cell Mol Biol 1993; 9: 568-572.

2. Seal E Jr, McDonnell WF, House DE, et al. The pulmonary response of white and black adults to six concentrations of ozone. Am Rev Respir Dis 1993; 147: 804-810.

3. Koren HS, Devlin RB, Becker S, Perez R, McDonnell WF. Time-dependent changes of markers associated with inflammation in the lungs of humans exposed to ambient levels of ozone. Toxicol Pathol 1991; 19: 406-411.

4. Blomberg A, Mudway IS, Nordenhäll C, et al. Ozoneinduced lung function decrements do not correlate with early airway inflammatory or antioxidant responses. Eur Respir $J$ 1999; 13: 1418-1428.

5. Mudway IS, Stenfors N, Blomberg A, et al. Differences in basal airway antioxidant concentrations are not predictive of individual responsiveness to ozone: a comparison of healthy and mild asthmatic subjects. Free Radic Biol Med 2001; 31: 962-974.

6. Schelegle ES, Siefkin AD, McDonald RJ. Time course of ozone-induced neutrophilia in normal humans. Am Rev Respir Dis 1991; 143: 1353-1358.

7. Stenfors N, Pourazar J, Blomberg A, et al. Effect of ozone on bronchial mucosal inflammation in asthmatic and healthy subjects. Respir Med 2002; 96: 352-358.

8. Balmes JR, Chen LL, Scannell C, et al. Ozone-induced decrements in FEV1 and FVC do not correlate with measures of inflammation. Am $\mathrm{J}$ Respir Crit Care Med 1996; 153: 904-909.

9. Holz O, Jorres RA, Timm P, et al. Ozone-induced airway inflammatory changes differ between individuals and are reproducible. Am J Respir Crit Care Med 1999; 159: 776-784.

10. Nightingale JA, Rogers DF, Barnes PJ. Effect of inhaled ozone on exhaled nitric oxide, pulmonary function, and induced sputum in normal and asthmatic subjects. Thorax 1999; 54: 1061-1069.

11. McBride DE, Koenig JQ, Luchtel DL, Williams PV, Henderson WR Jr. Inflammatory effects of ozone in the upper airways of subjects with asthma. Am J Respir Crit Care Med 1994; 149: 1192-1197.

12. Frampton MW, Balmes JR, Cox C, et al. Effects of ozone on normal and potentially sensitive human subjects. Part III: Mediators of inflammation in bronchoalveolar lavage fluid from nonsmokers, smokers, and asthmatic subjects exposed to ozone: a collaborative study. Res Rep Health Eff Inst 1997; 78: 73-79.

13. Montuschi P, Nightingale JA, Kharitonov SA, Barnes PJ. Ozone-induced increase in exhaled 8-isoprostane in healthy subjects is resistant to inhaled budesonide. Free Radic Biol Med 2002; 33: 1403-1408.

14. Graham DE, Koren HS. Biomarkers of inflammation in ozone-exposed humans. Comparison of the nasal and bronchoalveolar lavage. Am Rev Respir Dis 1990; 142: 152156.

15. Hiltermann JT, Lapperre TS, van Bree L, et al. Ozoneinduced inflammation assessed in sputum and bronchial lavage fluid from asthmatics: a new noninvasive tool in epidemiologic studies on air pollution and asthma. Free Radic Biol Med 1999; 27: 1448-1454.

16. Hermans C, Bernard A. Lung epithelium-specific proteins: characteristics and potential applications as markers. $\mathrm{Am} \mathrm{J}$ Respir Crit Care Med 1999; 159: 646-678.

17. Broeckaert F, Bernard A. Clara cell secretory protein 
(CC16): characteristics and perspectives as lung peripheral biomarker. Clin Exp Allergy 2000; 30: 469-475.

18. Hermans C, Petrek M, Kolek V, et al. Serum Clara cell protein (CC16), a marker of the integrity of the air-blood barrier in sarcoidosis. Eur Respir $J$ 2001; 18: 507-514.

19. Robin M, Dong P, Hermans C, Bernard A, Bersten AD, Doyle IR. Serum levels of CC16, SP-A and SP-B reflect tobacco-smoke exposure in asymptomatic subjects. Eur Respir J 2002; 20: 1152-1161.

20. Carbonnelle S, Francaux M, Doyle I, et al. Changes of serum pneumoproteins caused by short-term exposures to nitrogen trichloride in indoor chlorinated pools. Biomarkers 2002; 7 : $464-478$

21. Broeckaert F, Arsalane K, Hermans C, et al. Lung epithelial damage at low concentrations of ambient ozone. Lancet 1999; 353: 900-901.

22. American Thoracic Society. Lung function testing: selection of reference values and interpretative strategies. Am Rev Respir Dis 1991; 144: 1202-1218.

23. Bernard A, Marchandise FX, Depelchin S, Lauwerys R, Sibille Y. Clara cell protein in serum and bronchoalveolar lavage. Eur Respir J 1992; 5: 1231-1238.

24. Hermans C, Aly O, Nyberg BI, Peterson C, Bernard A.
Determinants of Clara cell protein $(\mathrm{CC} 16)$ concentration in serum: a reassessment with two different immunoassays. Clin Chim Acta 1998; 272: 101-110.

25. Stenfors N. Differential airway inflammatory responses to ozone and diesel exhaust in healthy and asthmatic subjects. Umeå: Umeå University, Sweden, 2002. PhD Thesis.

26. Hermans C, Bernard A. Pneumoproteinaemia: a new perspective in the assessment of lung disorders. Eur Respir $J$ 1998; 11: 801-803.

27. Broeckaert F, Arsalane K, Hermans C, et al. Serum clara cell protein: a sensitive biomarker of increased lung epithelium permeability caused by ambient ozone. Environ Health Perspect 2000; 108: 533-537.

28. Hazucha MJ, Bates DV, Bromberg PA. Mechanism of action of ozone on the human lung. J Appl Physiol 1989; 67: $1535-1541$.

29. Krishna MT, Springall D, Meng QH, et al. Effects of ozone on epithelium and sensory nerves in the bronchial mucosa of healthy humans. Am J Respir Crit Care Med 1997; 156: 943-950.

30. Nanson CJ, Burgess JL, Robin M, Bernard AM. Exercise alters serum pneumoproteins concentrations. Respir Physiol 2001; 127: 259-265. 